\title{
Correction: The histone methyltransferase DOT1L is a new epigenetic regulator of pulmonary fibrosis
}

Di Yang, Peng Xu, Haibi Su, Wen Zhong, Jie Xu, Zhenghua Su and Xinhua Liu (D)

(c) The Author(s) 2022

Cell Death and Disease (2022)13:153; https://doi.org/10.1038/s41419-022-04548-8

Correction to: Cell Death and Disease https://doi.org/10.1038/ s41419-021-04365-5, published online 17 January 2022

The original version of this article unfortunately contained a mistake in figures 1 and 2. The authors apologize for the mistake. The original article has been corrected.

Open Access This article is licensed under a Creative Commons Attribution 4.0 International License, which permits use, sharing, adaptation, distribution and reproduction in any medium or format, as long as you give appropriate credit to the original author(s) and the source, provide a link to the Creative Commons license, and indicate if changes were made. The images or other third party material in this article are included in the article's Creative Commons license, unless indicated otherwise in a credit line to the material. If material is not included in the article's Creative Commons license and your intended use is not permitted by statutory regulation or exceeds the permitted use, you will need to obtain permission directly from the copyright holder. To view a copy of this license, visit http://creativecommons. org/licenses/by/4.0/.

(c) The Author(s) 2022 